\title{
29. The liberalisation of FDI policies and the impacts of FDI on China's economic development
}

Chunlai Chen

Foreign direct investment (FDI) has been one of the most significant features of China's economic reform and opening up to the outside world. By the end of 2016, China had attracted a total of US\$1.35 trillion in FDI stock (UNCTAD various issues), making it the largest FDI recipient in the developing world. The large volumes of FDI inflows have contributed greatly to China's economy in terms of capital formation, employment creation, export expansion and technology transfer, and have exerted significant impacts on its economic growth and structural changes.

This chapter provides a brief review of the liberalisation and development of China's FDI policies since late 1978, discusses the main characteristics of FDI in China, examines the main impacts of FDI on China's economy and provides some policy suggestions for China to further attract and benefit from FDI.

\section{The background of China's opening up to FDI}

The shift in China's policies towards attracting FDI reflects important political changes. ${ }^{1}$ In 1975, when Deng Xiaoping emerged from political obscurity, he commissioned the drafting of a series of documents outlining the 'four modernisations - the modernisation of agriculture, industry, science and technology, and national defence- which were raised at the fourth National People's Congress in January of that year. The authors of these documents, and particularly Deng Xiaoping, believed the achievement of these modernisations and other such initiatives would be crucial to China's economic development. However, these efforts were fiercely attacked by radicals as 'capitalist' and, eventually, Deng was removed from all party and government posts.

It is no surprise that Deng Xiaoping reintroduced these ideas immediately after his return to power in 1978, and China's economic reforms were launched later that year. The ideas Deng had proposed in 1975-to introduce and acquire advanced technology and management methods from foreign countries-were developed

1 For a detailed discussion of the political implications of China's foreign trade and FDI reforms, see Shirk (1994). 
further to allow inward FDI into China's domestic economy. Drawing on the experience of other developing economies in attracting and utilising FDI, the Chinese leadership recognised that FDI was an effective way to acquire advanced technology and equipment from foreign countries quickly and with minimal cost. FDI was also a means of better utilising China's resources in the absence of domestic capital, and of providing valuable experience of modern economic management skills. It is clear the Chinese leadership was politically sincere in its desire to attract FDI, even though such investment also risked bringing capitalist influence into China.

The political endorsement of inward FDI in the late 1970s was rationalised by the necessity of achieving a recovery from the economic disruption caused by the Cultural Revolution. The search for foreign capital seemed to be inevitable. A package deal that provides technology, management skills and access to international markets, as well as capital, was naturally the best choice for China's decision-makers. The fundamental shift in Communist Party thinking from 'class struggle' towards 'socialist economic construction' and, even more significantly, the urgent demand for economic development greatly facilitated the initial changes to China's FDI policy. As a result, at the second session of the fifth National People's Congress in July 1979, the Law on Joint Ventures Using Chinese and Foreign Investment was passed, granting FDI legal status in China.

\section{The liberalisation of China's FDI policies and FDI inflows into China}

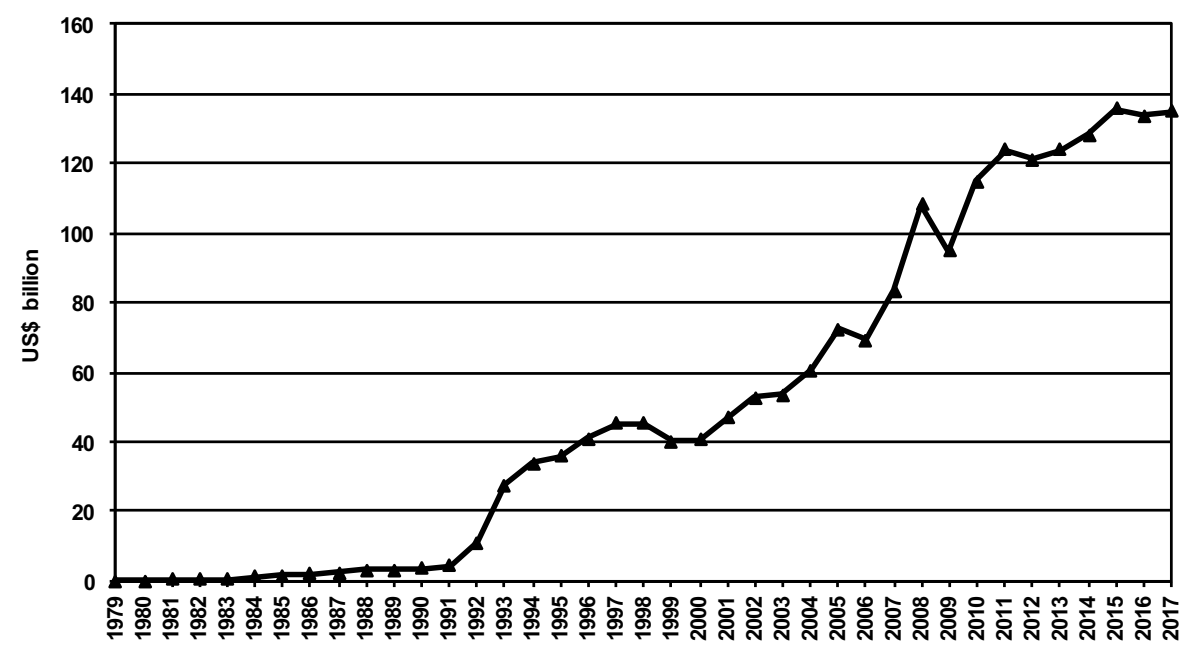

Figure 29.1 FDI inflows into China, 1979-2017 (current US\$)

Sources: UNCTAD (various issues). 
Figure 29.1 shows the growth of FDI inflows into China from 1979 to 2017 in three phases: 1979-91, 1992-2001 and 2002-17. In each phase, FDI inflows are closely related to the liberalisation and development of China's legal framework and FDI policies.

\section{The first phase, 1979-91}

Following the adoption of the 'open-door policy' in late 1978 and the release of the Equity Joint Venture Law in 1979, China established four special economic zones (SEZs)_Shenzhen, Zhuhai, Xiamen and Shantou-in Guangdong and Fujian provinces in 1980. During the period 1984-91, the Chinese Government made significant efforts to liberalise FDI policies and attract FDI inflows. This included opening more areas to FDI, such as Hainan Island and 14 coastal cities across 10 provinces in 1984; opening the Yangtze River Delta, the Pearl River Delta and the Min Nan Delta in 1985; and opening the Shanghai Pudong New Development Zone and then the entire coastal area to FDI in 1988 (Liu et al. 1993). To encourage FDI inflows, the Chinese Government offered special tax incentives to foreign investors, which are reflected in the Equity Joint Venture Income Tax Law, the Foreign Enterprise Income Tax Law and the Industrial and Commercial Tax Provisions.

The government also introduced a series of laws and regulations to encourage FDI inflows (Wei 1994; Chen 2011), including the Regulations for the Implementation of the Law on Chinese-Foreign Equity Joint Ventures in 1983, the Law on Enterprises Operated Exclusively with Foreign Capital and the Provisions of the State Council on the Encouragement of Foreign Investment in 1986 and the Law on Chinese-Foreign Contractual Joint Ventures in 1988.

The uneven regional implementation of the open strategy for FDI-from the SEZs to coastal cities and then to the entire coastal area-has enabled the coastal region to gain more benefits than others. Consequently, the gaps in economic development and income level between the coastal region and the inland areas have enlarged since the late 1980s. There have been benefits for the inland economies, but the process of diffusion from the coast to the inland has been slow. The outflow of skilled workers, technical personnel and capital from inland areas to the coastal region has been increasing (Chen 2017). In response, in the 1990s, the Chinese Government gradually moved the implementation of its FDI policies to create a more level playing field throughout the country.

In the first phase of opening to the world, because the Chinese Government was very prudent in introducing FDI into its domestic economy, foreign investors were cautious about investing in China. During the period 1979-91, FDI inflows into China averaged US $\$ 1.8$ billion annually. 


\section{The second phase, 1992-2001}

The second phase of FDI began in 1992, following Deng Xiaoping's tour of China's southern coastal, economically open areas and SEZs. Deng's tour set the scene for China's move away from the formerly uneven regional implementation to a nationwide application of open policies for FDI. The Chinese Government implemented a series of new policies and regulations that would encourage FDI inflows. These included gradually shifting the application of preferential FDI policies from regional to local and national industrial development priorities, and opening 52 cities to foreign investors. The preferential policies granted to the 14 coastal cities were applied to these new cities, and more than 15 border cities and counties in the south-west, north-west, north and north-east of China were declared open-border cities. Some services industries — such as aviation, telecommunications, banking and retail trade - were opened to FDI participation in a limited and experimental fashion. To further develop foreign trade and processing industries in coastal areas, more duty-free zones were to be established. In addition, the government allowed foreign businesspeople - those with an intention to set up FDI firms at a later stage and land developers - to buy land use rights for the building of infrastructure facilities, including residential, commercial, industrial and recreational real estate (Wei 1994). To boost economic growth and, therefore, to reduce the economic development gap between coastal, central and western regions, the Chinese Government launched the Western Development Strategy in 1998, which covered 12 provinces, municipalities and autonomous regions.

In the 1990s, the Chinese Government further liberalised its FDI regime. In 1990, the Amendments to the Equity Joint Venture Law and the Wholly Foreign-owned Enterprise Implementing Rules were adopted. New regulations adopted after 1991 included the Foreign Investment Enterprise and Foreign Enterprise Income Tax Law, the Copyright Law, the Software Protection Regulations, the Patent Law Amendments, the Trademark Law, the Regulatory Provisions of Foreign Banks, the Securities Exchange Law, the Banking Law, the Foreign Exchange Control Regulations, the Company Law, the Interim Provisions Concerning Some Issues on the Establishment of Companies Limited by Shares with Foreign Investment, the Interim Provisions on Guiding Foreign Investment Direction and the Catalogue for the Guidance of Foreign Investment Industries.

In the second phase, China established a more consistent and systematic FDI regulatory framework. The results were astounding. In 1992, inflows of FDI into China reached US\$11 billion, doubling the figure for 1991. In 1993, inflows doubled again, reaching US $\$ 27.5$ billion. The high growth of FDI inflows continued from 1994 to 1997; however, they slowed after 1997 and declined in 1999 and 2000, mainly because of the East Asian Financial Crisis, which substantially weakened the outward investment abilities of East and South-East Asian economies, which had been important investors in China. 


\section{The third phase, 2002-17}

The third phase began in 2002 after China's entry to the World Trade Organization (WTO) the previous year. In anticipation of China's entry to the WTO, the Chinese Government amended the Wholly Foreign-owned Enterprise Law and the Contractual Joint Venture Law in 2000 and the Equity Joint Venture Law in 2001. After entry, China issued a series of regulations to fulfil its commitments to the WTO. In 2005, the new Company Law was issued, simplifying company establishment requirements and expanding the rights of shareholders. In 2003, it issued the Interim Provisions on Mergers and Acquisitions of Domestic Enterprises by Foreign Investors and, after a three-year trial, the Regulations for Merger with and Acquisition of Domestic Enterprises by Foreign Investors were issued, in October 2006. These regulations established new rules for foreign investors acquiring interests in China's domestic companies, in line with international practice.

After more than 10 years of debate and drafting, China enacted its first AntiMonopoly Law in 2007. The Anti-Monopoly Law itself does not distinguish between foreign and domestic businesses. However, until July 2009, foreign investors were also subject to pre-merger notification and competition review under the provisions on mergers and acquisitions (M\&As). To ensure the M\&A provisions agreed with the Anti-Monopoly Law and the State Council's provisions on Thresholds for Declaration of Concentrations of Undertakings, the government revised the M\&A provisions in July 2009. Foreign buyers were then subject to only one competition notification and review requirement, under the Anti-Monopoly Law.

In March 2007, Chinese lawmakers passed the Enterprise Income Tax Law, unifying the tax rates for foreign and domestic enterprises. The new tax rate for both domestic and foreign enterprises was 25 per cent. The law took effect on 1 January 2008 and unified the tax rates for domestic firms and FDI. Many tax incentives and tax holidays for foreign investors in the old code were changed or eliminated.

In February 2002, China issued the Provisions on Guiding the Orientation of Foreign Investment, which classified FDI into 'encouraged', 'permitted', 'restricted' and 'prohibited' categories. The provisions encourage both a greater geographic dispersion of FDI inflows within China and greater FDI inflows into the targeted economic sectors and industries. To guide FDI into the targeted industries in accordance with China's economic and industrial development strategy, the government amended its Catalogue for the Guidance of Foreign Investment Industries in 2004, 2007, 2011, 2015 and 2017. The latest version, the 2017 catalogue, which took effect on 28 July, introduced a national negative list, specifying the industries in which FDI is restricted or prohibited. Industries falling under the 'restricted' category are subject to controls such as shareholding limits, and must receive prior approval from the Ministry of Commerce. Industries in the prohibited category are completely closed 
to FDI. The 2017 catalogue shows the Chinese market is continuing to open to foreign investors, with an overall trend of liberalisation. These changes demonstrate that China is serious about upgrading its industrial structure through utilising foreign capital to achieve sound economic development.

Two characteristics of regulatory change in the 2000s distinguish it from the 1980s and the 1990s. First, emphasis has been placed on the creation and development of a more consistent and systematic regulatory framework. Second, greater efforts have been made to conform to international FDI requirements.

In the third phase, after a period of falling FDI inflows, China's WTO accession was followed by a lift in such flows. FDI inflows increased from US $\$ 46.9$ billion in 2001 to US\$108.3 billion in 2008. However, the Global Financial Crisis saw inflows into China decline to US\$95 billion in 2009, before recovering to US\$114.7 billion in 2010 and US\$135 billion in 2017.

\section{The characteristics of FDI in China}

\section{The sources of FDI in China}

Table 29.1 presents the top 15 investors in China to the end of 2014. Hong Kong (China) holds the dominant position, followed by British Virgin Islands, Japan, the United States, Singapore, Taiwan (China), South Korea, Cayman Islands, Germany, Samoa, the United Kingdom, Netherlands, France, Mauritius and Macau (China). Together, the top 15 investors accounted for 87.5 per cent of total FDI inflows into China at the end of 2014.

Table 29.1 The top 15 FDI investors in China by the end of 2014

\begin{tabular}{|l|r|r|}
\hline & \multicolumn{2}{|c|}{ End 2014 } \\
\hline Hong Kong (China) & (US\$ billion) & \multicolumn{1}{|c|}{ (\%) } \\
\hline British Virgin Islands & 746.9 & 46.5 \\
\hline Japan & 141.8 & 8.8 \\
\hline United States & 98.6 & 6.1 \\
\hline Singapore & 75.4 & 4.7 \\
\hline Taiwan (China) & 72.3 & 4.5 \\
\hline Korea & 61.2 & 3.8 \\
\hline Cayman Islands & 59.9 & 3.7 \\
\hline Germany & 28.7 & 1.8 \\
\hline Samoa & 23.9 & 1.5 \\
\hline
\end{tabular}


29. The liberalisation of FDI policies and the impacts of FDI on China's economic development

\begin{tabular}{|l|r|r|}
\hline & \multicolumn{2}{|c|}{ End 2014 } \\
\hline & (US\$ billion) & \multicolumn{1}{c|}{ (\%) } \\
\hline United Kingdom & 19.2 & 1.2 \\
\hline Netherlands & 14.7 & 0.9 \\
\hline France & 13.6 & 0.9 \\
\hline Mauritius & 13.0 & 0.8 \\
\hline Macau (China) & 11.9 & 0.7 \\
\hline Others & 200.8 & 12.5 \\
\hline Total & $1,605.3$ & 100.0 \\
\hline
\end{tabular}

Source: MOC (2015).

FDI in China was dominated by developing economies, accounting for 68.7 per cent of the total (Figure 29.2). A large share was held by tax haven economies, accounting for 13.1 per cent of the total.

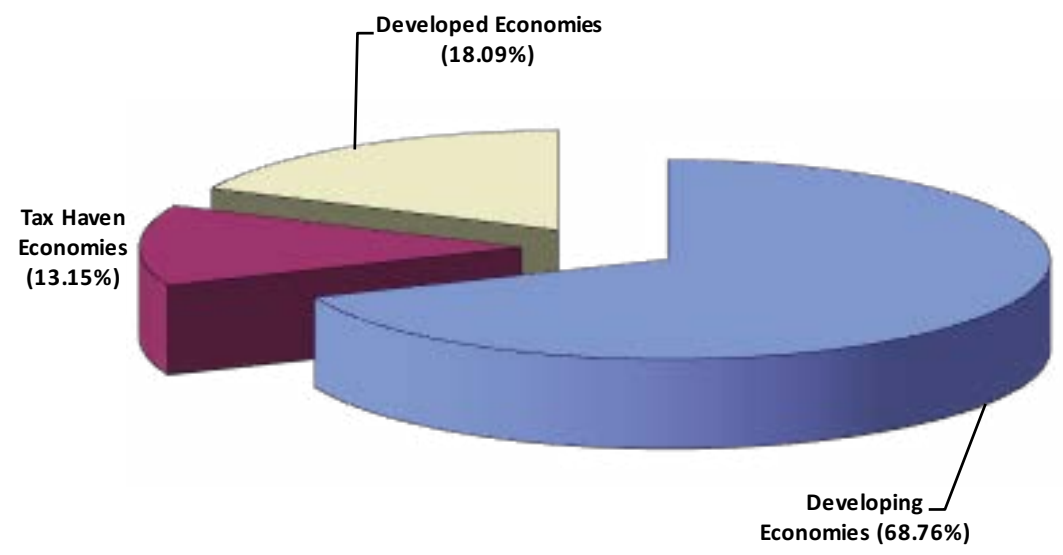

Figure 29.2 Sources of FDI in China by the end of 2014

Source: MOC (2015).

\section{The regional distribution of FDI in China}

FDI inflows have been concentrated overwhelmingly in the eastern region of China (Figure 29.3); however, inflows here have been slowing since 2012, alongside large increases in the central and western regions. Annual FDI inflows into the central region have reached more than US\$10 billion since 2009 and annual FDI inflows into the western region reached more than US\$10 billion in 2013 and 2014. 


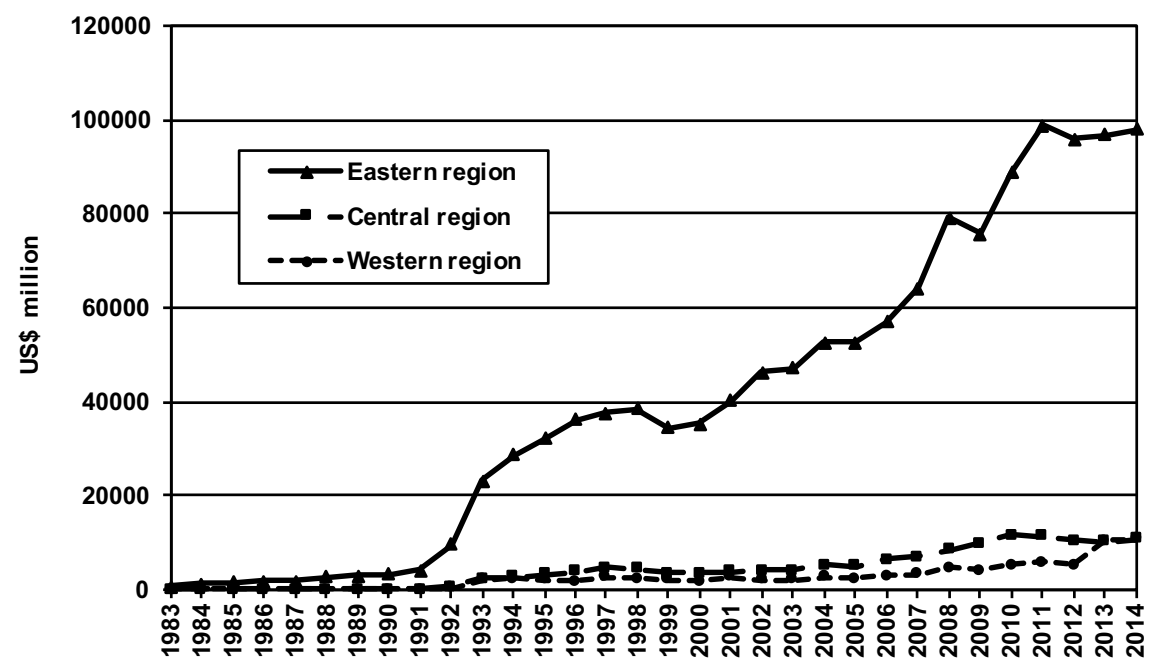

Figure 29.3 FDI inflows into China by region, 1983-2014 (current US\$) Sources: Data for 1983-2005 are from NBS (various issues); data for 2006-14 are from MOC (various issues).

From 1983 to 2014 , Guangdong (14.6 per cent) and Jiangsu (14.5 per cent) were the recipients of the largest amounts of FDI among China's eastern provinces, followed by Liaoning (8.7 per cent), Shanghai (7.1 per cent), Shandong (6.5 per cent), Fujian (5.9 per cent), Zhejiang (5.9 per cent), Tianjin (5.3 per cent) and Beijing (3.7 per cent). In the central region, Henan is the largest FDI recipient, attracting 3.3 per cent of the national total. In the western region, Sichuan attracted the largest amount of FDI inflows (2.7 per cent of the national total).

Overall, as Figure 29.4 shows, by the end of 2014, FDI in China was overwhelmingly concentrated in the eastern region, accounting for 85.2 per cent of the total.

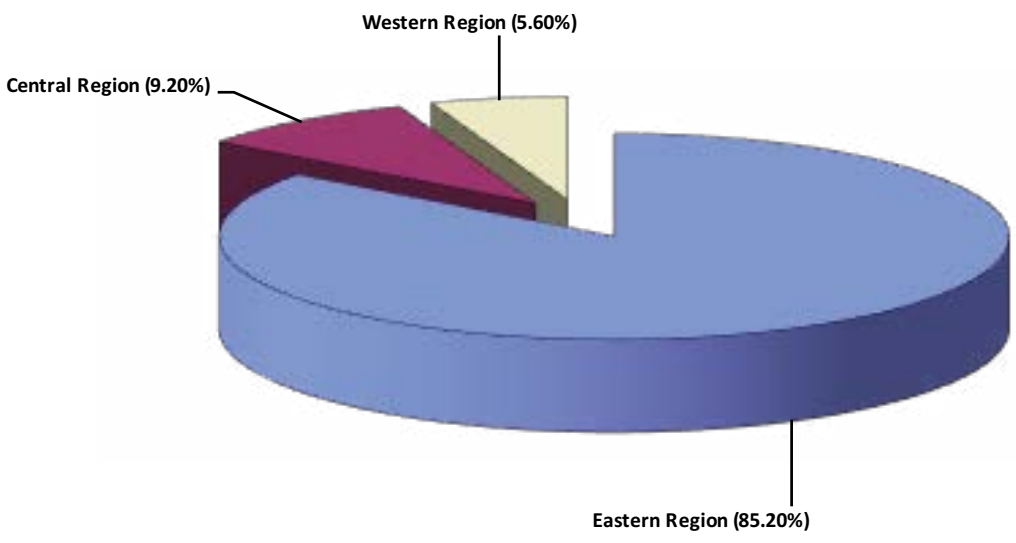

Figure 29.4 Regional distribution of FDI in China by the end of 2014

Sources: Data for 1983-2005 complied from NBS (various issues); and for 2006-14, from MOC (various issues). 


\section{Sectoral distribution of FDI in China}

FDI overwhelmingly flowed into the manufacturing sector before 2009 (Figure 29.5). However, since 2010, FDI inflows into the manufacturing sector have slowed, and declined after 2012. By contrast, FDI inflows into the services sector started to increase rapidly and surpassed inflows into the manufacturing sector in 2010. In 2014, FDI inflows into the manufacturing sector totalled US $\$ 39.9$ billion, while those for the services sector reached US $\$ 77.5$ billion—nearly double the amount into manufacturing.

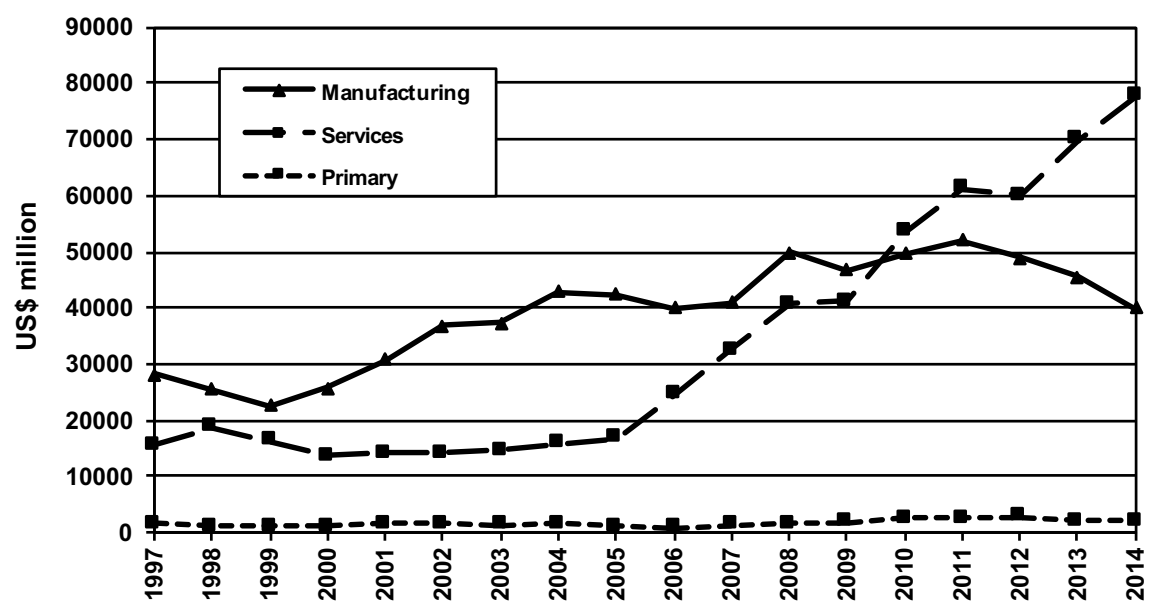

Figure 29.5 FDI inflows into China by sector, 1997-2014 (current US\$) Sources: NBS (various issues).

By the end of 2014, as shown in Figure 29.6, the manufacturing sector attracted 52.7 per cent, the services sector attracted 44.9 per cent, while the primary sector attracted only 2.3 per cent of total FDI inflows into China during the period $1997-2014 .^{2}$

Overall, FDI in China is characterised by the dominance of investors from developing economies, a heavy concentration of FDI in the coastal region and flows going overwhelmingly into the manufacturing sector before 2009, but increasingly into the services sector since 2010 .

2 Data for FDI inflows into sectors are not available before 1997. 


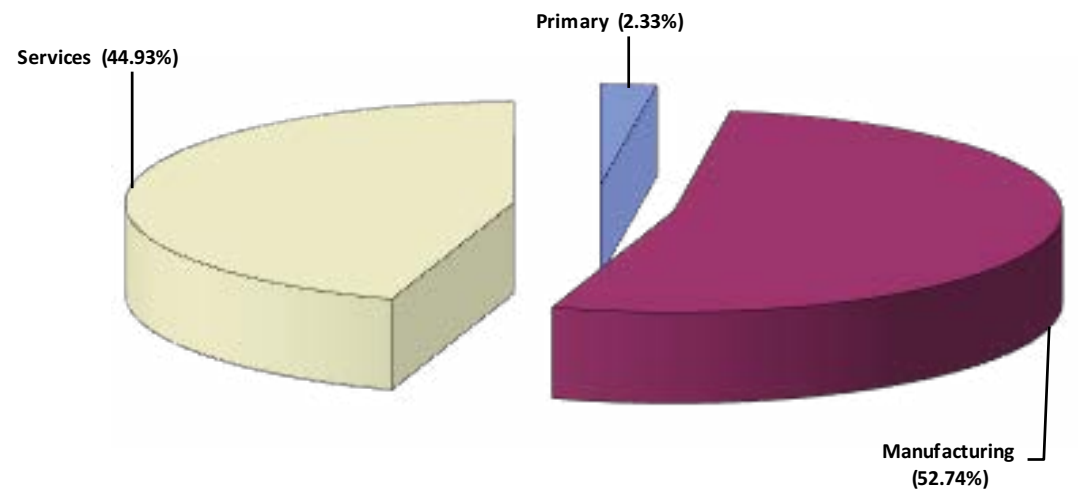

Figure 29.6 Sectoral distribution of FDI in China by the end of 2014

Sources: Compiled from NBS (various issues).

\section{The impacts of FDI on China's economic development}

According to Dunning's 'ownership advantage, location advantage and internalisation advantage' (OLI) framework (Dunning 1993), FDI brings with it a package of capital, technology, production know-how, modern management and marketing skills, information, competition and other firm-specific intangible assets. Therefore, it is expected that FDI will contribute to the host country's economic development through capital formation, employment creation, technology transfers and knowledge spillovers. During the past four decades, China has attracted large amounts of FDI inflows, totalling US\$1.35 trillion at the end of 2016. This section discusses how FDI has impacted China's economic development in terms of economic growth and productivity spillovers, export promotion, income distribution and urbanisation.

\section{Economic growth and productivity spillovers}

The increase in labour and capital inputs and advances in technology are sources of economic growth, to which FDI contributes through employment creation, capital formation, technology transfers and knowledge spillovers. FDI differs from domestic investment in three important aspects. First, FDI accelerates the speed of adoption of general-purpose technologies ${ }^{3}$ in host countries, each of which is capable of raising the aggregate productivity of labour and capital. Second, FDI is imbued with

3 General-purpose technologies are technological inventions that affect the entire global economic system. Some recent examples include the computer, the internet and the mobile phone. 
new technologies and other intangible proprietary assets otherwise unavailable in the host country. Such technologies can shift the host country's production frontier to a new level. Third, FDI may generate positive knowledge spillovers to boost the host country's economic growth. FDI can improve the productivity and efficiency of local firms through knowledge spillovers such as learning by doing or learning by watching (demonstration effects), research and development (R\&D), human resource movement, training, vertical industrial linkages, technical assistance and exposure to fierce competition.

How has FDI contributed to China's economic growth? FDI can promote China's economic growth through four channels. First, FDI inflows increase demand for labour and create employment. FDI firms hired 29.6 million workers, or 7.5 per cent of China's total urban employment, in 2014. The increase in employment contributes to an increase in total output, thus promoting economic growth. Second, FDI inflows increase China's fixed capital formation. By the end of 2016, China had attracted US\$1.35 trillion in FDI stock, which has contributed to the country's fixed capital formation and, therefore, boosted its economic growth. Third, FDI is a leading source of technology transfer and human capital augmentation in developing countries (Dunning 1993). FDI is therefore expected to accelerate China's economic growth through technological progress. Fourth, through knowledge spillovers, FDI is expected to increase the productivity and efficiency of domestic Chinese firms.

The impact of FDI on China's economic growth has been studied extensively, finding that FDI has played a positive role. For example, Chen et al. (1995) find that FDI has been positively associated with economic growth and an increase in total fixed investment in China. Dees (1998) finds evidence supporting the view that FDI affects China's growth through the diffusion of knowledge and ideas. Tang et al. (2008) find that FDI complements rather than crowding out domestic investment. FDI has not only assisted in overcoming a shortage of capital, it has also stimulated economic growth through complementing domestic investment in China. Whalley and Xin (2010) find that China's foreign-invested enterprises may have contributed more than 40 per cent of China's economic growth in 2003 and 2004 and, without this inward FDI, China's overall GDP growth rate could have been about 3.4 percentage points lower. Chen (2011) finds that FDI contributes to China's economic growth both directly through increasing capital input and indirectly through positive knowledge spillovers. During the period 1986-2005, of the 11.77 per cent average growth rate of China's real GDP, 1.4 percentage points came from direct and indirect contributions of FDI, which constituted 12.43 per cent of the total growth rate in that period.

Some empirical studies find that the economic and technological conditions of a recipient economy influence the extent to which FDI contributes to growth. For example, Buckley et al. (2002) find that the growth-promoting effects of FDI are more evident in the more developed provinces than in those that are less developed, 
and that the full benefits of FDI are realised when competition in local markets is at its strongest. Yao and Wei (2007) find that FDI has positive and significant impacts on China's economic growth; however, the positive impact is greater in the eastern than in the central and western regions. Tuan et al. (2009) find that while FDI exerted spillover effects and affected the total factor productivity (TFP) growth of the recipients, major technology and knowledge-related factors-including the R\&D and human capital of recipients_also played critical roles. Chen (2017) finds that FDI has contributed to China's economic growth directly through capital augmentation and technological progress and indirectly through knowledge spillovers to the local economy. That study also finds the contribution of FDI is influenced by local economic and technological conditions. FDI exerts a stronger impact on economic growth through capital augmentation and technological progress in the developed coastal provinces than in the less-developed inland provinces. While FDI has a positive and significant impact on economic growth through knowledge spillovers in the developed coastal provinces, such positive spillovers from FDI are absent in the less-developed inland provinces.

Empirical studies have also found evidence that FDI has generated positive productivity spillovers to China's domestic firms. For example, Xu and Sheng (2012) find that FDI has positive spillover effects on domestic firms' productivity in the same industry within the same region. Chen (2011) finds that FDI has significant positive spillover effects on the productivity of Chinese domestic firms within the same industry in the manufacturing sector. However, the study finds that FDI does not have significant spillover effects on domestic firms' productivity through backward and forward industrial linkages. This is mainly because of FDI firms' heavy engagement in processing trade, which breaks down the industry linkages between FDI and domestic firms. These suggest that host countries could enlarge the positive spillover effects of FDI and thereby foster domestic firm productivity by strengthening industrial linkages between domestic and FDI firms.

\section{Export promotion}

FDI has played a significant role in China's export expansion. Figure 29.7 presents the export performance of FDI firms from 1986 to 2014. FDI firms' exports rose from US\$600 million in 1986 to US\$791 billion in 2008 and to US\$1 trillion in 2014. As a result, the importance of FDI firms to China's exports increased from only 1.9 per cent in 1986 to 45.9 per cent in 2014, and FDI firms have rapidly become a major exporting group. 


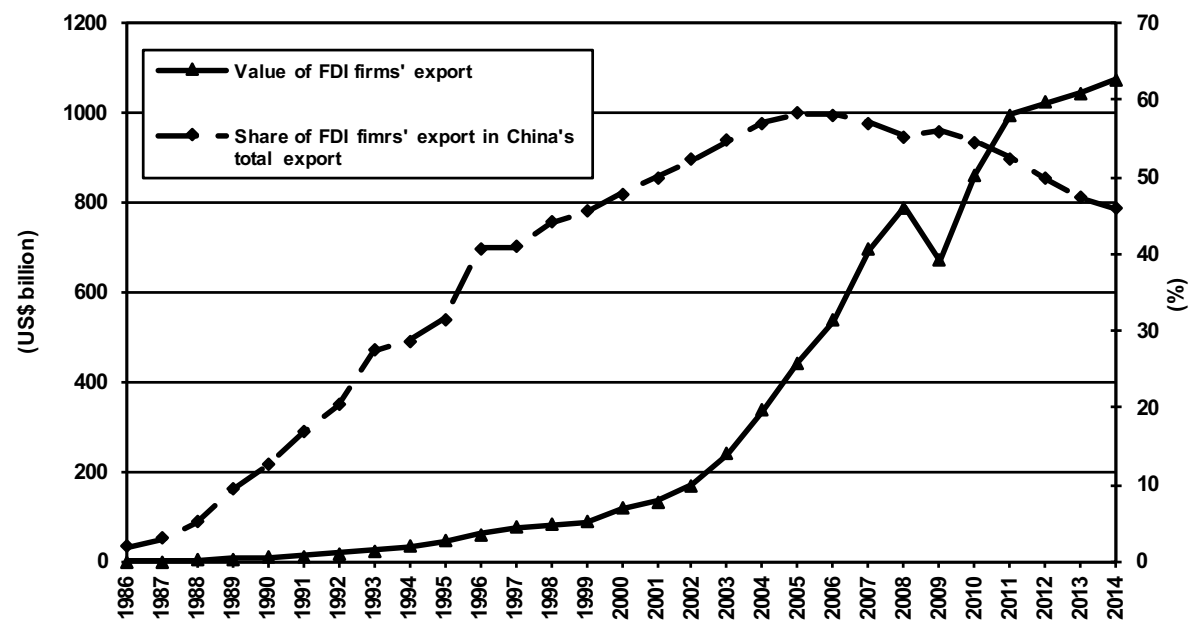

Figure 29.7 Export performance of FDI firms, 1986-2014 (current US\$) Source: MOC (2015).

One significant feature of FDI in promoting China's international trade is its heavy engagement in processing trade, ${ }^{4}$ especially in the coastal region. As Table 29.2 shows, during the period 2002-12, FDI firms' processing trade accounted for more than 80 per cent of China's total processing trade and more than 60 per cent of FDI firms' total trade. In particular, FDI firms' processing exports accounted for more than 70 per cent of their total exports.

Table 29.2 The performance of FDI firms' processing trade, 2002-12

\begin{tabular}{|l|c|c|c|}
\hline Year & $\begin{array}{c}\text { FDI firms' processing } \\
\text { trade as a percentage } \\
\text { of China's total } \\
\text { processing trade }\end{array}$ & $\begin{array}{c}\text { FDI firms' processing } \\
\text { trade as a percentage } \\
\text { of FDI firms' } \\
\text { total trade }\end{array}$ & $\begin{array}{c}\text { FDI firms' processing } \\
\text { exports as a } \\
\text { percentage of FDI } \\
\text { firms' total exports }\end{array}$ \\
\hline 2002 & 75.7 & 69.3 & 79.2 \\
\hline 2003 & 79.6 & 68.2 & 79.2 \\
\hline 2004 & 81.9 & 67.9 & 78.7 \\
\hline 2005 & 83.7 & 69.5 & 78.0 \\
\hline 2006 & 84.9 & 68.1 & 76.5 \\
\hline 2007 & 84.3 & 66.1 & 74.9 \\
\hline 2008 & 84.5 & 63.1 & 72.4 \\
\hline
\end{tabular}

4 Processing trade activities include 'processing or assembling with imported materials' and 'processing or assembling with supplied materials'. For the former, processing firms import—free of customs duty—materials and components that are used to produce finished goods and export them to international markets. In the case of processing or assembling with supplied materials, the processing firms process or assemble duty-free materials and components supplied by foreign firms and export finished products. They are paid a fee for the processing or assembling activities. The foreign firms control both the supply of the materials and all the international marketing of the processed or assembled products. 


\begin{tabular}{|l|c|c|c|}
\hline Year & $\begin{array}{c}\text { FDI firms' processing } \\
\text { trade as a percentage } \\
\text { of China's total } \\
\text { processing trade }\end{array}$ & $\begin{array}{c}\text { FDI firms' processing } \\
\text { trade as a percentage } \\
\text { of FDI firms' } \\
\text { total trade }\end{array}$ & $\begin{array}{c}\text { FDI firms' processing } \\
\text { exports as a } \\
\text { percentage of FDI } \\
\text { firms' total exports }\end{array}$ \\
\hline 2009 & 84.1 & 62.8 & 73.4 \\
\hline 2010 & 83.9 & 60.7 & 72.0 \\
\hline 2011 & 83.1 & 58.3 & 70.3 \\
\hline 2012 & 81.7 & 58.0 & 69.9 \\
\hline
\end{tabular}

Sources: Calculated from MOC (various issues; 2015).

Empirical studies have found strong evidence that FDI promotes Chinese exports and that the relationship between FDI inflows and bilateral trade is complementary (for example, Lardy 1995; Chen 1999; Hu and Ma 1999; Liu et al. 2001; Li 2003).

However, are there impacts from FDI on the exports of China's domestic firms? Theoretically, FDI firms can generate export spillovers to domestic firms through three main channels. First, FDI firms can reduce the export costs of domestic firms through knowledge spillovers, thus encouraging domestic firms to increase exports (for example, Aitken et al. 1997; Greenaway et al. 2004). Second, FDI firms can generate positive technology spillovers to domestic firms to increase their productivity, which may improve their competitiveness and increase their exports (for example, Barrios et al. 2003; Javorcik 2004). Third, FDI firms can strengthen domestic industrial linkages through supplying and purchasing intermediate inputs, which not only will increase the productivity of domestic firms in the upstream and downstream industries, but also will promote their involvement in international production specialisation, thus enhancing domestic firms' ability to export (for example, Javorcik 2004; Kneller and Pisu 2007).

Empirical studies have found strong evidence that FDI has positive spillover effects on the export decisions and performance of Chinese domestic firms (for example, Zheng et al. 2004; Ma 2006, Buck et al. 2007; Cheung 2010; Sun 2012). However, such effects vary across regions and among different types of firms. For example, Sun (2009) finds that FDI has stronger spillover effects on domestic exports in the coastal region than in inland regions. Chen (2011) finds that FDI firms have a positive impact on the export propensity of domestic firms in the same industry through demonstration effects, and this is generated mainly by high-exporting FDI firms. The study also finds some evidence that FDI firms - in particular, highexporting FDI firms-have positive export spillover effects on domestic firms in downstream industries through forward industrial linkage, meaning domestic firms can access good-quality and cheap intermediate inputs from upstream FDI firms. Such firms can therefore reduce their production costs, improve competitiveness and increase exports. However, the study does not find significant evidence that FDI firms - particularly high-exporting ones-generate export spillover effects to domestic firms through backward industrial linkage. One explanation is that FDI 
firms in China are highly engaged in processing trade and therefore generate no significant backward spillover effects to domestic firms. Chen et al. (2013) find that FDI firms have generated positive export spillover effects on Chinese domestic firms' export decisions, export-sales ratio and export value. However, these effects are most likely to be observed in domestic enterprises that are not state-owned.

\section{Income distribution}

For the past 40 years, China has achieved remarkable results in increasing per capita income and improving the living standards of the Chinese people, which has been attributed to rapid economic growth. Despite this, income inequality in China has actually worsened. Based on the government's official calculations, the Gini coefficient reached 0.49 in 2008, before falling to 0.46 in 2015 (China Economy Net 2016). Has FDI contributed to increasing or reducing income inequality in China? It is expected that FDI will affect the host country's income distribution through its contribution to economic growth, changing resource endowments and its impacts on employment and wage structures. Theoretically, according to the Kuznets inverted-U curve hypothesis (Kuznets 1955), income inequality increases in the early stage of development, but declines once a certain stage of development is reached. Empirical evidence shows that FDI contributes to developing countries' economic growth and development (for example, Dunning 1993; Caves 1996). As a result, although FDI may initially increase income inequality, its benefits will eventually spread throughout the whole economy and it could in the long run facilitate more even income distribution in developing countries through its development effects (Tsai 1995; Chen 2017). Furthermore, FDI brings capital into capital-scarce developing countries, which not only increases their productive capital stock, but also changes their capital-labour ratio (Dunning 1993). As a result, FDI inflows should reduce the relative returns on capital of labour and, therefore, reduce income inequality in capital-scarce developing countries (Lin et al. 2013). In addition, FDI creates employment, which is especially important in developing countries with a large amount of surplus labour. According to the conventional Heckscher-Ohlin model and the Stolper-Samuelson theorem (Krugman and Obstfeld 1991), if a developing country is relatively well-endowed with unskilled labour, to take advantage of the relatively abundant factors of production, FDI should be concentrated in activities that use that unskilled labour more intensively (Lee and Vivarelli 2006; Ucal et al. 2014). As a result, FDI should lead to an increase in the demand for unskilled labour, which not only increases the incomes of previously unemployed labourers, but also drives up the wages of unskilled workers relative to those of skilled workers. Consequently, income inequality will decline as FDI increases. Therefore, through economic growth and development, capital formation and employment creation, FDI tends to reduce income inequality in developing countries. 
However, some empirical studies have found that FDI has contributed to the widening of income inequality between the inland and coastal regions in China (for example, Zhang and Zhang 2003; Fu 2004). Wan et al. (2007) find that the effects of FDI contribute to a positive and substantial share of regional inequality and the share rises over time.

In contrast, Jalil (2012) finds that income inequality rises with the increase of economic openness (measured by the openness of FDI and trade) and then starts to fall once that openness reaches a critical point. Chen (2016) finds that FDI has directly contributed to reducing urban-rural income inequality through employment creation for rural unskilled labour, knowledge spillovers from labour movement and economic development of the local economy, which contribute to increasing rural household incomes. Chen (2017) finds that the impact of FDI on urban-rural income inequality is not linear. Overall, empirical studies reveal that while FDI in China has contributed to a widening of the income gap between the coastal and inland regions, it has also contributed to a reduction in income inequality, especially urban-rural income inequality, as FDI continues to increase.

\section{Urbanisation}

Urbanisation is the shift of population from rural to urban areas and the gradual increase in the proportion of people living in urban areas. People are motivated to leave the primary sector to work in the secondary and tertiary sectors and migrate from rural areas to urban areas because of push factors from the countryside and pull factors from the city. On the one hand, during the process of economic development and the expansion of industrialisation and urbanisation, the traditional agricultural sector will decline and many farmers will lose their land, which will produce a large surplus of rural labourers, who will be pushed into cities to look for jobs. On the other hand, the expansion of modern manufacturing and services sectors in cities will provide a lot of employment opportunities and higher incomes, which will pull surplus rural labour into urban areas.

How has FDI impacted China's urbanisation rate? By the end of 2016, China had attracted US\$1.35 trillion in FDI stock, of which 97 per cent was in the secondary and tertiary sectors. FDI has therefore played a significant role in China's economic development and structural change and has greatly enhanced both the push and pull forces for urbanisation.

The share of the value of the primary sector in GDP declined from 27.9 per cent in 1978 to 9.2 per cent in 2014 , while the share of the value of the secondary and tertiary sectors increased from 72.1 per cent to 90.8 per cent in the same period. Despite the decline of the primary sector, however, China's agricultural productivity has grown rapidly since the start of reforms in 1978. The large volumes of FDI 
inflows have led to more efficient resource allocation, rapid dissemination of new agricultural technologies (including improved seed varieties and animal breeds) and the widespread application of agricultural mechanisation. These have laid a broad foundation for improved agricultural productivity (Wang et al. 2013; Zhang and Wan 2015). The decline of the share of the primary sector in the national economy and the increase in agricultural productivity have produced large numbers of surplus rural labourers, many of whom have been pushed to migrate to urban areas to look for new employment opportunities.

Second, FDI inflows have led to large-scale land acquisition in China (Li et al. 2016), in which governments acquire rural land to lease to urban businesses, especially to FDI firms. In China, land acquisition has been a common practice for local governments to boost economic growth. While the pace of industrialisation and urbanisation accelerates due to the effects of FDI inflows, Chinese officials estimate that approximately 2 million rural residents lose their land each year (Nelson 2012). Once an agreement is reached between local governments and rural collectives, farmers receive compensation and are moved to newly built resettlement housing in urban or peri-urban areas, becoming in effect formal urban residents ( $\mathrm{Li}$ et al. 2016).

In terms of the pull factors, while FDI has predominately flowed into the secondary and tertiary sectors, it has led to the rapid development of labour-intensive and export-oriented manufacturing sectors. This has created huge employment opportunities and has absorbed most of the surplus rural labour in urban areas. As a result, FDI firms have hired large numbers of rural migrants. For example, in the manufacturing sector, FDI firms hired more than 26 million workers, accounting for one-third of China's manufacturing labour force in 2008 (Chen 2011); and in the national economy, FDI firms hired 29.6 million workers or 7.5 per cent of China's total urban employment in 2014 (NBS various issues). Therefore, the increasing labour demand in urban areas due to FDI inflows will continue to pull surplus rural labour to the cities.

Second, FDI firms in China tend to pay their employees higher wages than do domestic firms. In the manufacturing sector, on average, the wages paid by FDI firms are more than two times higher than those of domestic firms (Chen 2011). This not only increases the average wage in the manufacturing sector, but also can produce positive spillover effects on the wages of domestic firms when they compete in the labour market. In addition, FDI may also increase overall income levels in urban areas. Both factors will encourage surplus rural labour to move to cities to seek new jobs and higher incomes.

Empirical studies using national, regional and provincial-level data find that FDI has made a significant contribution to urbanisation in China. However, this positive impact is greater in coastal than in inland provinces (for example, Shi and Hamnett 2002; Zhang 2002; Chubarov and Brooker 2013). A number of studies using city- 
level data for all prefecture cities in China find similarly positive impacts. These impacts, however, vary from region to region, with a positive impact in coastal cities, but no significant impact in inland cities (Wu and Chen 2016). In addition, FDI in the coastal region has a negative interregional impact on urbanisation in inland cities (Chen and Wu 2017). This is related to the massive migration of labour from inland rural areas to coastal urban areas because of the large volume of FDI inflows there, which impedes the process of inland urbanisation.

\section{Conclusion}

During the past four decades, China's change of attitude from restricting to passively attracting and then to actively seeking inward FDI has been fully reflected in the evolution of its FDI policies, laws and regulations. In all policy relating to FDI, the Chinese Government has been taking a positive but gradual approach to reform. In general, this process has proved relatively successful, which has been reflected in the quality of the evolving foreign investment environment and the rapid growth of FDI inflows into China.

Although China has achieved substantial progress in its FDI policy liberalisation, its current FDI policy can be further improved, particularly in respect to transparency, market access and the protection of intellectual property rights. With respect to the principle of transparency, China maintains a complex application process for FDI approval, which could be simplified and made more transparent through further policy liberalisation.

In terms of market access, although the 2017 catalogue signals an attempt to build a friendlier investment environment for foreign investors in China, it does not remove as many restrictions as those investors had hoped. The European Union Chamber of Commerce in China (2017), for example, said the catalogue falls short of expectations, and they would like to see it removed entirely in favour of a shorter and more simplified negative list. The protection of intellectual property rights has long been an issue in China. The weak enforcement of such protection not only has a negative impact on foreign investors' decisions to bring technology into the country, but also could have negative impacts on China's industrial upgrading and the diffusion of knowledge spillovers from FDI to the domestic economy (Chen 2011). Although there have been some improvements, especially since China's accession to the WTO, it is still very important for China to further strengthen intellectual property rights protection.

The uneven regional distribution of FDI, which is concentrated in the coastal region, has greatly contributed to the economic growth of coastal provinces. However, empirical studies reveal that this has had negative impacts on inland provinces in terms of economic growth, urban-rural income inequality and urbanisation rates 
(for example, Fu 2004; Chen 2015, 2017). China should therefore design policies to help improve economic and technological conditions in inland regions, as well as the overall investment environment, to attract greater FDI inflows. The launch of the Western Development Strategy in 1998 was an important step in the right direction and the implementation of the One Belt and One Road initiative since 2013 will further improve the investment environment in the inland regions. At the same time, these regions should maximise their advantages of cheap labour and land to attract FDI and domestic firms from the coastal region and abroad, to promote economic growth and development. Finally, China should encourage and enhance knowledge spillovers from FDI to its economy. The Chinese Government should encourage contact, information exchange, production and technological cooperation, joint $\mathrm{R} \& \mathrm{D}$ activities, industrial linkages as well as competition between FDI firms and domestic firms in general and between coastal FDI firms and inland firms in particular, to accelerate the diffusion of positive knowledge spillovers from FDI to China's economy.

\section{References}

Aitken, B., Hanson, H. and Harrison, A. (1997), Spillovers, foreign direct investment, and export behaviour, Journal of International Economics 43(1): 103-32. doi.org/10.1016/S0022-1996(96)01464-X.

Barrios, S., Gorg, H. and Strobl, E. (2003), Explaining firms' export behaviour: R\&D, spillovers and the destination market, Oxford Bulletin of Economics and Statistics 65(4): 475-96. doi.org/10.1111/1468-0084.t01-1-00058.

Buck, T., Liu, X., Wei, Y. and Liu, X. (2007), The trade development path and export spillovers in China: A missing link?, Management International Review 47(5): 683-706. doi.org/10.1007/s11575-007-0040-2.

Buckley, P., Clegg, J., Wang, C. and Cross, A. (2002), FDI, regional differences and economic growth: Panel data evidence from China, Transnational Corporations 2(1): $1-28$.

Caves, R. (1996), Multinational Enterprise and Economic Analysis, 2nd edn, Cambridge: Cambridge University Press.

Chen, C. (1999), The impact of FDI and trade, in Y. Wu (ed.), Foreign Direct Investment and Economic Growth in China, Cheltenham, UK: Edward Elgar.

Chen, C. (2011), Foreign Direct Investment in China: Location determinants, investor differences and economic impacts, Cheltenham, UK: Edward Elgar. doi.org/ $10.4337 / 9781781001141$. 
Chen, C. (2015), Do inland provinces benefit from coastal foreign direct investment in China?, China \& World Economy 23(3): 22-41. doi.org/10.1111/cwe.12112.

Chen, C. (2016), The impact of foreign direct investment on urban-rural income inequality: Evidence from China, China Agricultural Economic Review 8(3): 480-97. doi.org/10.1108/CAER-09-2015-0124.

Chen, C. (2017), Foreign Direct Investment and the Chinese Economy: A critical assessment, Cheltenham, UK: Edward Elgar. doi.org/10.4337/9781785369735.

Chen, C. and Wu, Y. (2017), Interregional impact of foreign direct investment on China's inland urbanisation, Singapore Economic Review 63(1): 1-21.

Chen, C., Chang, L. and Zhang, Y. (1995), The role of foreign direct investment in China's post-1978 economic development, World Development 23(4): 691-703. doi.org/10.1016/0305-750X(94)00143-M.

Chen, C., Sheng, Y. and Findlay, C. (2013), Export spillovers of FDI on domestic firms, Review of International Economics 21(5): 841-56. doi.org/10.1111/ roie. 12074 .

Cheung, K. (2010), Spillover effects of FDI via exports on innovation performance of China's high-technology industries, Journal of Contemporary China 19(65): 541-57. doi.org/10.1080/10670561003666152.

China Economy Net (2016), China's Gini coefficient is 0.462 in 2015: The lowest in 12 years, [in Chinese], China Economy Net, 19 January. Available from: www.ce.cn/xwzx/gnsz/gdxw/201601/19/t20160119_8372526.shtml.

Chubarov, I. and Brooker, D. (2013), Multiple pathways to global city formation: A functional approach and review of recent evidence in China, Cities 35(8): 181-9. doi.org/10.1016/j.cities.2013.05.008.

Dees, S. (1998), Foreign direct investment in China: Determinants and effects, Economics of Planning 31(2): 175-94. doi.org/10.1023/A:1003576930461.

Dunning, J. (1993), Multinational Enterprises and the Global Economy, Wokingham, UK: Addison-Wesley.

European Union Chamber of Commerce in China (2017), Revised foreign investment catalogue falls short of expectations, Press release, 5 July, Beijing: European Union Chamber of Commerce in China. Available from: www. europeanchamber.com.cn/en/press-releases/2568/revised_foreign_investment_ catalogue_falls_short_of_expectations. 
Fu, X. (2004), Limited linkages from growth engines and regional disparities in China, Journal of Comparative Economics 32(1): 148-64. doi.org/10.1016/j. jce.2003.10.004.

Greenaway, D., Sousa, N. and Wakelin, K. (2004), Do domestic firms learn to export from multinationals?, European Journal of Political Economy 20(4): 1027-43. doi.org/10.1016/j.ejpoleco.2003.12.006.

$\mathrm{Hu}, \mathrm{X}$. and Ma, Y. (1999), International intra-industry trade of China, Review of World Economics 135(1): 82-101. doi.org/10.1007/BF02708160.

Jalil, A. (2012), Modelling income inequality and openness in the framework of Kuznets curve: New evidence from China, Economic Modelling 29(2): 309-15. doi.org/10.1016/j.econmod.2011.10.012.

Javorcik, B. (2004), Does foreign direct investment increase the productivity of domestic firms? In search of spillovers through backward linkages, The American Economic Review 94(3): 605-27. doi.org/10.1257/0002828041464605.

Kneller, R. and Pisu, M. (2007), Industrial linkages and export spillovers from FDI, The World Economy30(1): 105-34. doi.org/10.1111/j.1467-9701.2007.00874.x.

Krugman, P. and Obstfeld, M. (1991), International Economics: Theory and policy, 2nd edn, New York: Harper Collins.

Kuznets, S. (1955), Economic growth and income inequality, American Economic Review 45(1): 1-28.

Lardy, N. (1995), The role of foreign trade and investment in China's economic transformation, The China Quarterly 144: 1065-82. doi.org/10.1017/ S0305741000004732.

Lee, E. and Vivarelli, M. (2006), The social impact of globalization in the developing countries, IZA Discussion Paper No. 1925, Bonn: Institute of Labor Economics. Available from: ftp.iza.org/dp1925.pdf.

$\mathrm{Li}$, B., Chen, C. and Hu, B. (2016), Governing urbanization and the new urbanization plan in China, Environment and Urbanization 28(2): 515-34. doi.org/10.1177/0956247816647345.

Li, Y. (2003), The impact of FDI on trade: Evidence from China's bilateral trade, Journal of the Academy of Business and Economics 2(2): 1-11.

Lin, S., Kim, D. and Wu, Y. (2013), Foreign direct investment and income inequality: Human capital matters, Journal of Regional Science 53(5): 874-96. doi.org/10.1111/jors. 12077 . 
Liu, X., He, C., Lu, Z., Fan, B. and Zhou, J. (eds) (1993), Guide to China's Foreign Economic and Trade Policies, Beijing: Economic Management Press.

Liu, X., Wang, C. and Wei, Y. (2001), Causal links between FDI and trade in China, China Economic Review 12(2-3): 190-202.

Ma, A. (2006), Export spillovers to Chinese firms: Evidence from provincial data, Journal of Chinese Economic and Business Studies 4(2): 127-49. doi.org/10.1080/ 14765280600736908.

Ministry of Commerce (MOC) (various issues), Foreign Investment Report, Beijing: Ministry of Commerce of China.

Ministry of Commerce (MOC) (2015), Statistics on FDI in China, 2015, Beijing: Ministry of Commerce of China.

National Bureau of Statistics (NBS) (various issues), China Statistical Yearbook, Beijing: China Statistics Press.

Nelson, C. (2012), Land reform effects in China, China Business Review: The Magazine of the US-China Business Council, 1 October. Available from: www.chinabusinessreview.com/land-reform-efforts-in-china/.

Shi, Y. and Hamnett, C. (2002), The potential and prospect for global cities in China: In the context of the world system, Geoforum 33(1): 121-35. doi.org/ 10.1016/S0016-7185(01)00026-4.

Shirk, S. (1994), How China Opened its Door: The political success of the PRC's foreign trade and investment reforms, Washington, DC: The Brookings Institution.

Sun, S. (2009), How does FDI affect domestic firms' exports? Industrial evidence, World Economy 32(8): 1203-22. doi.org/10.1111/j.1467-9701.2009.01175.x.

Sun, S. (2012), The role of FDI in domestic exporting: Evidence from China, Journal of Asian Economics 23(4): 434-41. doi.org/10.1016/j.asieco.2012.03.004.

Tang, S., Selvanathan, E. and Selvanathan, S. (2008), Foreign direct investment, domestic investment and economic growth in China: A time series analysis, World Economy 31(10): 1292-309. doi.org/10.1111/j.1467-9701.2008.01129.x.

Tsai, P. (1995), Foreign direct investment and income inequality: Further evidence, World Development 23(3): 469-83. doi.org/10.1016/0305-750X(95)00136-Z.

Tuan, C., Ng, L. and Zhao, B. (2009), China's post-economic reform growth: The role of FDI and productivity progress, Journal of Asian Economics 20(3): 280-93. doi.org/10.1016/j.asieco.2009.02.010. 
Ucal, M., Bilgin, M. and Haug, A. (2014), Income inequality and FDI: Evidence with Turkish data, MPRA Paper No. 61104, Munich: Munich Personal RePEc Archive. Available from: mpra.ub.uni-muenchen.de/61104/.

United Nations Conference on Trade and Development (UNCTAD) (various issues), World Investment Report, New York and Geneva: United Nations Publications.

Wan, G., Lu, M. and Chen, Z. (2007), Globalization and regional income inequality: Empirical evidence from within China, Review of Income and Wealth 53(1): 35-59. doi.org/10.1111/j.1475-4991.2007.00217.x.

Wang, S., Tuan, F., Gale, F., Somwaru, A. and Hansen, J. (2013), China’s regional agricultural productivity growth in 1985-2007: A multilateral comparison, Agricultural Economics 44(2): 241-51. doi.org/10.1111/agec.12008.

Wei, J. (1994), Chinese Foreign Investment Laws and Policies: Evolution and transformation, Westport, CT: Quorum Books.

Whalley, J. and Xin, X. (2010), China's FDI and non-FDI economies and the sustainability of future high Chinese growth, China Economic Review 21(1): 123-35. doi.org/10.1016/j.chieco.2009.11.004.

Wu, Y. and Chen, C. (2016), The impact of foreign direct investment on urbanization in China, Journal of the Asia Pacific Economy 21(3): 339-56. doi.org/ 10.1080/13547860.2016.1176641.

$\mathrm{Xu}, \mathrm{X}$. and Sheng, Y. (2012), Are FDI spillovers regional? Firm-level evidence from China, Journal of Asian Economics 23(3): 244-58. doi.org/10.1016/j.asieco. 2010.11.009.

Yao, S. and Wei, K. (2007), Economic growth in the presence of FDI: The perspective of newly industrializing economies, Journal of Comparative Economics 35(1): 211-34. doi.org/10.1016/j.jce.2006.10.007.

Zhang, K. (2002), What explains China's rising urbanization in the reform era?, Urban Studies 39(12): 2301-15. doi.org/10.1080/0042098022000033881.

Zhang, X. and Zhang, K. (2003), How does globalization affect regional inequality within a developing country? Evidence from China, Journal of Development Studies 39(4): 47-67. doi.org/10.1080/713869425.

Zhang, Y. and Wan, G. (2015), International trade and urbanization in developing countries: Evidence from Asia, Social Sciences in China 36(2): 186-204. doi.org/ 10.1080/02529203.2015.1029679.

Zheng, P., Siler, P. and Giorgioni, G. (2004), FDI and the export performance of Chinese indigenous firms: A regional approach, Journal of Chinese Economic and Business Studies 2(1): 55-71. doi.org/10.1080/14765280310001631381. 
This text is taken from China's 40 Years of Reform and Development: 1978-2018, edited by Ross Garnaut, Ligang Song and Cai Fang, published 2018 by ANU Press, The Australian National University, Canberra, Australia.

doi.org/10.22459/CYRD.07.2018.29 